\title{
An Insecure Base? Nerves, Violence and Step-Parents in Norwegian Children's Literature
}

\author{
Anne-Kari Skardhamar
}

Central issues represented in four recent Norwegian books for children are children's resistance to step-parents, children's attempts to cope with family violence, and inverted relationships where children take responsibility for mentally unstable parents. The literary texts I have chosen as examples are three novels: Ingeborg Arvola's Blod, snørr og tårer (2000) (Blood, Snot and Tears); Kristin A. Sandberg's Verdens ondeste stemor (2004) (The World's Worst Stepmother); Endre Lund Eriksen's Pitbull-Terje går amok (2002) (Pitbull Terrier Runs Amok); and Gro Dahle and Svein Nyhus's picture book Sinna mann (2003) (Angry Man) My aim in this article is to explore how problems and survival strategies of children in troubled families are described and developed in these texts, and what stylistic devices and narrative techniques are employed. My analysis of the representations of nerves, violence and step-parents in four children's books draws on arguments from theories about philosophy and literature in general, children's literature, narrative analysis and attachment theories in child psychology.

\section{Literature and representations of life}

TheAmerican philosopher and literary critic Martha Craven Nussbaum claims that literature has an important function as a fictitious construction of life. She refers to her early years of adolescence when she, then as well as later in life, thought that the most fruitful and natural way to pursue philosophical questions was to turn to works of literature: 'It seemed to me best to discuss the issues in connection with a text that displays concrete lives and told a story; and to discuss them in ways that responded to these literary features' (Nussbaum 1990, p.12). This is not the same as seeing fictitious characters merely as constructed 'cases, persons as subjects of medical or welfare attention. It is also a question of the language and artistic quality of the literary text, since 'certain truths about human life can only be fittingly and accurately stated in the language and forms characteristic of the narrative artist', and life is 'never simply presented by a text; it is always represented as something. This "as" can, and must, be seen not only in the phrasable content, but also in the style, which itself expresses choices and selections, and sets up, in the reader, certain activities and transactions rather than others' (Nussbaum 1990, p.5).
Nussbaum's argument about literary representations of life is the point of departure for my study of fictitious children in troubled families. Her claim that the style and aesthetic expression count is equally important to my examination of the four books and leads to a combination of thematic and narrative analysis. Nussbaum's statements concern literature in general, but is also applicable to children's literature. Style and language may be particularly important in the interpretation of children's literature, as the authors often adapt their language to the assumed capacities of their child readers.

\section{Four case studies in children's fiction}

Social and psychological studies may be constructed and introduced as children's narratives. They may be regarded as an integral element of the kinds of children's books which thematise emotional problems and for instance explore children's need for a secure base and attachment figures, the effects of divorce on children, the breaking of affectional bonds, loss of love, inadequate parenting, inverted parenthood and children's dilemmas of loyalty. The child and family psychiatrist John Bowlby explored the effects of adverse events in childhood in real life and documented the effects of attachment figures in A Secure Base (1988) and explained emotional patterns in certain situations in The Making and Breaking of Affectional Bonds (1979). Some of his ideas may serve as models for explaining the behaviour of fictitious children.

The four books on which I focus all have boys as their main characters. In Arvola's novel the boy is ten, in Sandberg's and Eriksen's the boys are twelve years old, whereas in the picture book Sinna mann the main character is younger, maybe about seven, as he still sits on his mother's lap for comfort, but is old enough to write a short letter. The protagonists are all in situations where their secure base is threatened and their attachment figures seem to fail and leave the child alone. Bowlby claims that all human beings af all ages need 'one or more trusted persons who will come to their aid should difficulties arise. The person trusted, also known as an attachment figure, can be considered as providing his (or her) companion with a secure base from which to operate' (Bowlby 1988, p.103). 
The main plot in Sandberg's and Arvola's novels concerns how to handle a presumed intruder like a stepfather or a stepmother. Eriksen's and Dahle's books have mental suffering and violence as their main motif. Eriksen combines the three motifs of bullying, anxiety and violence. Family violence is described in detail in Sinna mann. A little boy lives with his biological parents, but does not feel his home as a secure base. His father's outbursts of violence, his transformation of character and his attacks are frightening for the little boy.

\section{Wicked steps - resistance and attachment behaviour}

In Sandberg's and Arvola's novels the problem for the protagonists is how to cope with the new partners of their parents, preferably how to get rid of them. Sandberg's Verdens ondeste stemor (The World's Worst Stepmother) is the simplest of the four books, as the problem is easily and amusingly solved. A father finds a new girl-friend whom his son dislikes and actively opposes. The boy is worried he might lose his father's care and attention as he feels pushed aside by the intrusive step-to-be, and his behaviour aims at protecting his own relationship with his father by demonstrating what Bowlby called attachment behaviour. Bowlby did not employ Freudian terms by describing behaviour as infantile or regressive, but explained attachment behaviour as a natural way of behaving with 'an urgent desire for love and care' (Bowlby 1988, p. 82). In order to obtain love and care and keep his father to himself, the boy attempts to frighten the new stepmother away by making life as unpleasant as possible for her.

Characteristic of the narrative technique in Sandberg's book is a consistent use of the first-person narrator. The boy who suffers from conflicts, loss and the experience of crises is the narrator, and his opponents are described from his viewpoint. The first-person narrator is active in the dynamic shaping of the text's action and events. He combines the function of narrator and character (Lothe 2003, p.21). This gives the narrator liberty to exaggerate, caricature and comment ironically upon his assumed enemies.

Exaggerations, parody and irony are the most important tools by which the first-person narrator in Sandberg's novel creates a humorous effect. The stepmother seems to have extremely bad taste, is unbelievably untidy and exhibits unpredictable and sometimes hyperactive behaviour. She dresses like Little Red Riding Hood or wears a leopard patterned dress and paints the kitchen to match her clothes. When the boy arranges to get rid of her by making the stairs slippery for her to fall and break her legs, his own father is caught in the trap and sent to hospital. In this way a certain amount of slapstick humour is employed to appeal to the readers and make them align themselves with the narrator's point-of view.

The first-person narrator is able to express his aggression, whilstalso depicting himself as an innocent victim of the evil acts of the others. By doing so he sometimes also without intention reveals his own folly, a point which invites the reader to negotiate about alternative ways of handling a family situation with a supposedly evil intruder. Several crucial incidents conveyed by the first-person narrator in a mode of parody and caricature reveal misunderstandings and the lack of communication in the family. The focalised character fails in his attempts at solving his own problem by assuming a hostile attitude.

Resistance and irony do not take him anywhere. He gradually realises that his hostility is destructive, his stepmother tells him about a trauma in her life, and the boy has to reconsider his judgement of her. The book is explicitly dedicated 'to all who have to live in two nuclear families', and thereby invites young readers to negotiate the issue of commuting between two homes and perhaps adjust their idea of what it means to have a secure base and how to co-operate to keep it.

The same strategy of resistance with a similar humorous effect is employed by the boy who is the first-person narrator in Arvola's novel, Blod, snørr og tårer (Blood, Snot and Tears). There a mother finds a new boyfriend whom her son strongly opposes. Supported by his best friend the boy protests by means of verbal abuse and by damaging his stepfather's computer and the tyres of his car. These destructive survival strategies demonstrate the boy's helpless attempts at protecting his attachment to his mother and claiming her full attention. The problem may be serious enough, as the boy wets his bed at night and struggles to conceal the evidence. 
However, more subtle patterns are indicated in this story. The boy's mother is an artist who appears as a strong and independent person, reluctant to conform to the code of her neighbourhood. She is also an escapist who avoids the problem of her son's wet bedclothes by pretending everything is all right, ignores the problem and never mentions it. Her son is attached to her, but he apparently wants more attention than his mother is able to give him. She used to pay him to get out of her way for a while when he was younger, while she also insisted on her love for him. There are hints to his mother's childhood as the only daughter-possibly motherless and emotionally neglected - of a very strict and rather unconventional man, to whom his daughter wants to mark her distance after his death. The mother herself as a child may have suffered from the lack of a secure base, and readers are positioned to wonder whether her family patterns are on the point of being repeated.

Like the boy in Sandberg's book, Arvola's boy character gradually and reluctantly realises that his assumed enemy may be reliable and friendly. The intruding 'step' shows patience and understanding, even care and friendship, and is a professional communicator, a psychiatrist. He wants to discuss the problems, has a good sense of humour and proves to be a good companion and a secure base for his step-son. The result is that the boy develops confidence that the step-parent will be helpful when appealed to, and the boy becomes increasingly secure and co-operative. The stepfather helps in solving conflicts among the boys and also encourages the main character to make up with his best friend. There is only one nuclear family in Arvola's story as the boy's biological father is never mentioned.

The two books are both narrated in chronological order, except that in Blod, snørr og tårer (Blood, Snot and Tears) a few fragments of analepsis occur. In short flashes the narration returns to earlier points in the story as the main character tries to find out what happened to his best friend, and whether his friend long ago really had tried to signalize that something was wrong in his family. Blood stains on the carpet is one of the visual impressions that the narrator keeps coming back to. Gradually he adds his observations into a meaningful pattern, and the story of violence in his friend's family is revealed.
Thus the story in Arvola's book is more complicated than Sandberg's rather simple narrative. Arvola's main plot is intertwined with two other stories, one of bullying and one of serious family violence. The main character experiences his situation as being under double pressure. $\mathrm{He}$ is bullied at school unless he behaves subservient to the leaders of the gang of boys in the schoolyard, and he himself adapts a bullying attitude in order to obtain acceptance and recognition.

The character's insistence on a step conflict gains depth and perspective by being linked to violence in the story of the main character's friend, whose father is imprisoned for violent attacks and serious injuries to his wife and son. The development of an empathetic and helpful attitude to his friend in distress is stimulated and supported by the stepfather, who eventually indirectly exposes the problems he himself has survived in a troubled family. His story serves as a turning point in the story of the hostile stepson. The boy's own problem is not insoluble as his stepfather makes no attempt to demonstrate power or expose jealousy. Resistance as a survival strategy for the boys in Sandberg's as well as in Arvola's novel has to be reconsidered and replaced by co-operation to solve the problem. The story ends by indicating that friendship, empathy and solidarity may make life easier as the three outsider children join to establish an exclusive secret club.

The discourse of the first-person narrative in Arvola's book includes a few extracts from the the boy's diary. The boy writes it for money, not for the pleasure of doing it, and he does not make much of an effort to do it properly. The discourse of the novel is not identical with the diary as one might have expected. The lack of discursive similarity is obvious in the quotation from the last page of the diary which is an ultra short summary of the writer's situation written in a minimalistic, paratactic style where most of the sentences starts with 'I'. This style may be a sign of his reluctance to writing at all, and possibly also a charcteristic of a ten year old boy's self indulgence in a situation where he is fighting to secure his base and defend his rights.

The discrepancy between the discourse of the main character's diary and the discourse of the novel shows that there must be an invisible external narrator behind the first- 
person child narrator though focalisation never changes to any of the other characters. The consistent perspective of the boy who is the narrator 'situate events within the character's mind but also maintain a separate narrating voice' (Stephens 1999, p.81), as may be seen from the slipping between free indirect thought:'When he asks me to come and play football after school, I shake my head and say I have to go home' and direct thought: 'And that he calls to care!' (Arvola 2000, p.128). The first-person narrator also uses present tense narration, and its effect is 'to convey an illusion of immediacy and instantaneity, suppressing any suggestion that the outcome is knowable in advance'(Stephens 1999, p.79). These linguistic strategies are employed to give the reader the opportunity to follow the first-person narrator's reflections and the development of his attitudes. The outcome is not a closing of meaning, but a widening of perspective.

In Arvola's story there are also strong elements of humour and irony in the speech of the characters, and there are comic episodes, for instance when the boy makes a firecracker explode just as his mother kisses her boyfriend. When the boy insists that his mother loves him and not his stepfather, the latter returns the boy's irony:'Yes, isn't it peculiar. I do my very best to be as snotty as you are' (p.37). When his mother remarks that the reason why she had a child was that she wanted some wet and dirty clothes to hang up, the boy is conscious of her irony and also of his own use of irony. He is ironic in his comments regarding his own pretended incompetence: 'I know mum is ironic when she says things like that, but I am only ten. Who said I would understand irony' (p.90). The place name of their residential area, 'Lykkelunden', the Happy Wood, is also ironic.

The elements of style mentioned above all contribute to the register of the novels, 'the principle which governs the choice among various possible lingustic realisations of the same thing' and 'refers to types of language variations' (Stephens 1999, p.78), in the case of Arvola's book a kind of early adolescent discourse characterised by a strong taste for irony. This mode of language is supposed to appeal to young readers and give them the illusion of being the narrator's buddies or confidants.

\section{Nerves and aggression - inverted parenting}

While Sandberg and Arvola describe children's reluctance to share their attachment figure with a step-parent, the problems in Eriksen's book seem more complicated and less easily solvable. In Pitbull-Terje går amok (Pitbull Terrier Runs Amok) there are two boys living in single parent families. The mother of the central character and first-person narrator suffers from a severe nervous disease, anxiety and depression, the father of the other boy, who appears to be quite helpful and friendly, also has a darker side, is inclined to drinking and has outbursts of violence. However, there are no intruding step candidates in the story.

The main character has developed great sensitivity and attentiveness, and he behaves like a caregiving and responsible adult in relation to his timid little mother. Their relationship is an illustration of inverted parenting, when children feel responsible for looking after their parents instead of the parents caring for them. Bowlby refers to studies of mothers who have a tendency 'to expect and demand care and attention from their own children, in other words to invert the relationship' (Bowlby 1988, p.18). The boy seems to cope fairly well, but occasionally he exposes his own anxiety when he checks the dark corners of the room because of his fear of darkness. The boy's strategy for survival is triple: firstly, he sticks to his and his mother's maxim of keeping up a positive attitude, and secondly he practises his sense of humour by employing metaphors that amuse his mother, e.g. when she ventures out he calls her Mrs. Armstrong and proclaims with an inverted quotation from early space adventures that her step outside the secure door is a little step for humanity but a big step for her (p.77), or when he several times prescribes lobotomy as a cure when she feels scared. His third survival strategy is to withdraw to a secret hiding place where he can avoid his mother's sighs and be able to relax.

As in Arvola's novel there is a serious conflict in Eriksen's Pitbull Terrier Runs Amok between a strong group of boys and the soft and childish main character, who is used as a slave, or alternatively bullied by the rulers. When a new fat boy is introduced into their class, the conflict increases. The main character wants to avoid being utterly degraded by being left in the newcomer's company, whereas the newcomer makes considerable efforts to win his alliance. 
When the secret hiding place of the main character is invaded and occupied and the boy himself is driven out, he joins the new boy to recapture his lost fort. The project fails, but the two boys eventually make friends and unite against their common enemies.

The book ends on Christmas Eve when the narrator's nervous mother cancels her Christmas celebrations, and the violent father in a fit of aggression flings his Christmas decorations out of the window while his son escapes by lowering a rope made of sheets and runs away. The two boys celebrate Christmas together and decide they will try to make a couple of their difficult parents. The adult reader may doubt if that is a good idea. In Pitbull Terrier Runs Amok two stories are interwoven, but here, as well as in Sandberg's and Arvola's novels, the chronology is strictly kept through the first-person narrator's observations, which allows no shifts of perspective nor shifts of place or time.

All the three books use expressions and a vocabulary coloured by what boys of ten and twelve would be likely to use. In addition the main characters are individualised by the way they speak. Eriksen's first-person narrator has a well developed ability to create metaphors to describe his emotions: 'Mum is yelling. It is burnings inside me. It is likely I have some sort of scrape in there. On my heart' (p.172). He has also taken over clichés from adults and made them part of his own language: 'what counts is to have a positive attitude', for example when he wants to break a complicated lock: 'Now I see that it may work. With a good wrecking bar and a positive attitude' (p.87).

With Eriksen, there is humour in the description of episodes and in verbal expressions. The new boy threatens his enemies with a furious pitbull terrier. The dog turns out to be a product of his imagination to keep others at a distance from his flat in order to cover up for his neurotic father. Grotesque episodes are also comical, as when the boys borrow a dog from an old lady and shave it to make it look like a pitbull. The use of images also contributes to the humorous effect: 'Stupid as a scone and as popular as mumps and pneumonia together' (p.110). The scared mother uses black humour and self-irony when she asks her son for a lobotomy and takes a sedative 'at the risk of being cured' (p.158).
All the three novels combine representations of serious social and psychological problems with a humorous and ironic style belonging to boys who want to mark a distance to their inadequate adults while they also want them to be their secure base. This combination may stimulate the reader's identification with the fictitious characters and accordingly the discussion about how to solve problems in real life. Stephens states that 'transactions between writers and readers take place within complex networks of social relations by means of language' (Stephens 1999, p.73). Though to foresee what possible reflections and transactions the narratives set up in the child readers may be complicated, as children's books mainly are written by adults for children.

Peter Hunt points out that the 'forness' of children's literature is judged differently by different generations. $\mathrm{He}$ is critical of the tradition of didacticism, which holds that children's books must be moral and educational and sees it as a 'consequence of adult dominance when both the child characters and the child reader are subservient to the adult voice in the book' (Hunt 2001, p.5). While Jacqueline Rose in 1984 claimed that children's fiction is 'impossible' because it hangs on the impossible relationship between adult and child (Watson 2001, p.185) and leaves undisturbed psychic barriers between adult and child, David Rudd argues that her emphasis needs shifting as there seems to be 'a disturbing recognition of the frailty of such barriers', and he quotes the children's writer John Gordon: 'The boundary between imagination and reality, and the boundary between being a child and being an adult are border country, a passionate place in which to work' (Rudd 1999, p. 21).

\section{Family violence - tell it and write it}

Angry Man, the picture book by Gro Dahle and Svein Nyhus, is different from the other texts I have discussed, not only by being a picture book, and not only because the main character is much younger than the others, but rather because of its poetic and dramatic representation of a serious problem, a violent father. The sons of violent fathers in Arvola's book, the stepfather and the main character's friend, both feel guilty for having told on their fathers and regret having done so (p.170). The boys report their violent fathers in order to protect their mothers, and 
telling the truth results in help from external professionals or even the police.

In Dahle's and Nyhus' picture book Sinna mann (Angry Man) the motif of the victim's sense of guilt is further elaborated. It is not the feeling of guilt for reporting, but for causing the violence. The little boy wonders about his father's violent attacks: 'Is it my fault?' The little boy seems to have developed an extreme sensibility and ability to observe his father's changing mood. His feeling of guilt may be explained as the victim's shame and feeling of being responsible for the abuse that happens to his mother when she tries to protect him. His father's violence may be a mixture of anger and despair. According to Bowlby, jealousy of a wife's attention to the child is a common precipitate of a husband's violence (Bowlby 1988, p. 93). The narrative proceeds to show the father's development from a big, furious father to a small and broken father, who needs help and treatment, and his process of healing is described with great sensitivity.

The little boy's survival strategy is to be on watch, not to annoy his father and provoke an outburst of the angry man who lurks behind his father. The boy wants to get out, but he feels shut up behind a thousand doors and has to open them himself. He is also shut up as regards his urge to tell about his unpleasant experiences, but his words 'are bursting and pressing and hammering, wanting to come out', and he opens up and tells the neighbour's dog, the birds and the tree. Eventually he writes a letter:

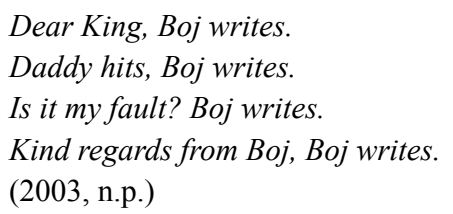

Dahle's book thus implies a metafictive element, with its suggestion of the importance of telling the story. The family problems have to be verbally expressed, and the boy's question about his own guilt needs to be answered. So it is when the King knocks on his door and assures him that it is not his fault that his father is violent. The adult reader understands that the dog owner, the lady with glasses so thick that she can see very well, is probably the one who conveys the boy's message and provides external support and therapeutic treatment.

Dahle's solution seems to evoke compassion rather than blame, as the boy's mother afterwards soothes her remorseful husband and wraps his hands in white silk handkerchiefs. In the boy's mind his father is 'little Dad' who is not identical with the angry man, not a villain himself, but a victim of possession by an uncontrollable evil spirit called 'angry man'. There is an 'old angry man' behind the 'angry man', 'an angry grumpy-mouldy shuffling old man' whom Dad also needs to talk to, he needs to hold the old angry man's hand and cuddle him on his lap. This may be interpreted as an illustration of the assumption that 'violence in families tends to perpetuate itself from one generation to the next' (Bowlby 1988, p.77), and that by means of psychotherapy the violent person as well as the adult reader may see the point in Bowlby's thesis that 'a great deal of the maladaptive violence met with in families can be understood as the distorted and exaggerated version of ... attachment behaviour on the one hand and caregiving behaviour on the other' (Bowlby 1988, p. 81). In Sinna mann (Angry Man) the villain is also a victim.

The story is told by an invisible third-person narrator, and the narrator leaves the perspective to the boy who wonders: 'Is Daddy quiet? Is Daddy happy?' While the third-person narrator is 'active in the plot, i.e. in the dynamic shaping of the text's action, events and characters', he does not participate in the action. His function is more purely communicative (Lothe 2003, p.21). That is the position of the narrator in Dahle's book. The central character here is younger than the boys in the three other books and therefore does not have the same command of language for telling his story as a first-person narrator. Another reason may be that the problems of violence and insecurity, the lack of a secure base or attachment to a reliable father figure are too serious to be left to a very young narrator. Besides, the consequence of the boy's experiences is that his words are locked up so that he cannot tell. His story needs an external narrator who can observe and tell.

The narrative perspective, however, is linked to the main character, the little boy called Boj, and 'indicates the vision through which the narrative elements are presented'(Lothe 
2003, p.39). The viewpoint, judgements and experiences are related to the boy. The effect of the perspective in this book may be dual address, to appeal to the intended child reader as well as to the adult reader, such as parents, teachers, psychologists or social workers.

The narrative strategy in Sinna Mann (Angry Man) is more complex. The iconotext, the interaction of words and pictures, is fundamental for the interpretation of the development of the plot, events and characters. An external narrative voice, which may interpret the scenes for the benefit of the child readers, has been replaced by the representation and implicit interpretation of scenes and incidents in the pictures. Peter Hunt claims that reading a picture book is an extremely sophisticated art (Hunt 2001, p.288), and according to Perry Nodelman 'picture books work to make their audiences aware of the limitations and distortions in their representations of the world. Close attention to picture books automatically turns readers into semioticians' (Nodelman 2005, p.137). In Angry Man the pictures visualize and elaborate and thus gradually interpret what the verbal text merely indicates.

Angry Man has eighteen double pictures which supplement the words and give emphasis to elements only suggested in the written text. Danger is emphasised by flame figures on the wall paper and the almost empty yellow plate of raisins on the edge of the table. The plate may fall down and break at any time. The most threatening detail is a hammer lying on the chest of drawers near the goldfish bowl. The goldfish bowl serves as a parallel to Boj's family. It contains a big black fish with a protruding jaw and a sinister expression, swimming in the centre of the bowl. A big red fish is swimming near the surface, and a small 'child' fish down below. Mother and child fish turn in the same direction, the black fish goes the oppsite way. Beside the chest of drawers with the fish bowl the little boy is sitting quietly with his pen and paper. The lack of coloured pencils and drawings on his paper underlines the impression of a boy being alert and continually observing his father's unpredictable and changing mood. The boy interprets signs and expresses his impressions by means of similes. The boy admires his father and wants to be as big and good as he: 'My Daddy', he says, but his father is an unreliable and distorted attachment figure.
The next three double pages present warnings of change in his father as he turns his back to the reader and has a small head and big hands. The clock shows five minutes to twelve (2-4). The following pictures show 'angry man' in action, orange and yellow like fire, the boy covers his head and ears, the clock is twelve, and the father's arms are beyond normal dimensions as he squeezes his doll-size wife in his fist (5-7). Picture eight shows the boy after he has happily escaped outside, playing with a big white dog. Pictures 9-11 show his grey, bent father's remorse and despair, a broken doorlock and a broken plate and the little boy who tries to embrace his father's leg. Picture twelve shows the father's attempts at reconciliation and atonement. A gift box is placed before the little boy, but he seems reluctant to touch it. Pictures 13-15 show the boy's suffering as he tells the white dog and writes a letter. Pictures number16-18 show the solution and the possibility that everything will be better for the boy and his parents. The white dog, a butterfly, the king and the lady with thick glasses are all there in the background while father and son are playing. Laughter and security will be achieved; the boy's toy aeroplane, that has been present in several pictures, is flying out of the picture. The solution lies in the future and is not guaranteed, but there is hope.

Dahle's book lacks comical situations and humorous effects. The problems here are no laughing matter for a third person narrator, and the main character is too young to use black humour as a survival strategy. Instead of humour the picture book uses employs images and poetic language to express or contrast with the violent action and frightening colours and exaggerated figures of the pictures. The layout of the text is like irregular stanzas of a poem, and the language is characterized by ellipses, repetitions and metaphors:
And Boj tells
the bushes and the birds and the grass
and the climbing tree.
The tree listens with every single leaf
and carries Boj right into the wind,
the clouds and the sky.
Go on telling, the tree whispers in the wind.
Tell it. Tell it....
All doors wide open.
Sunshine and breath and wind in his hair.
(2003, n.p.) 
Metaphors also occurs in the ordinary text for instance when the father sits in his chair and 'draws curtains' to his eyes and 'shuts his face with dense lids'. There are 'deadlocks on his father's voice and sharp edges', and behind the door behind his voice is 'a dark cellar'. When the boy wants to tell, 'his mouth is locked by seven locks, glued by super-glue and nailed by a hundred nails'. The violent father regrets, and 'kneels to the King' and seeks comfort on the King's lap. The metaphors and poetic expressions convey the emotions, the anxiety, the longing, the survival strategy and the resilience of the little boy. Besides, the effect of the poetic discourse is comforting and soothing, as the white silk handkerchiefs of the mother soothe the remorseful father.

\section{Resilience and didacticism}

All the books dealt with in this article construct representations of social situations where a child experiences a crisis in the family - split families or parents with nervous disorders or violent behaviour. The four books have in common that they treat family problems directly and describe the struggle of the child. All the books keep the convention of an ending that, if it is not happy, at least provides hope that conditions will improve.

The children in all the books seem to come through their crisis safe and sound and may be called 'resilient children'. They seem to be able to recover from difficult conditions, to recoil and spring back into shape after having been bent, stretched or compressed. In recent psychological literature 'resilience' refers to a dynamic process between a child in troubled families and its surroundings, and denotes a child's positive development and ability to cope when there are protecting factors around him (Sommer 2003, p.38 ff). The boys in these four books all develop survival strategies which include finding someone to share the problems with or be supported by. The happy or at least hopeful ending of the books about children in troubled families can be seen as a didactic strategy of encouraging children to keep up their courage in difficult situations. Contents and themes are 'representations of social situations and values, and such social processes are inextricable from the linguistic processes which give them expression' (Stephens 1999, p.73). Values and virtues like empathy, care, solidarity, communication and co-operation are highlighted in all of the books, and humour or poetic language are modes in which they are conveyed.

The World's Worst Step-mother, Blood, Snot and Tears and Pitbull Terrier Runs Amok may not give the impression of belonging to the didactic tradition as they do not prescribe one solution, but describe the problems, question the attitudes and thus encourage the reflections of the reader. Nevertheless there are underlying didactic programmes and conclusions as the books advocate certain values and achieve a balance between idyll and realism, despair and hope. In this respect the books fit into the didactic tradition: to please and to instruct.

Martha Nussbaum emphasises the importance of how the literary texts are read and used. She is concerned with 'what is embodied in the text and what the text, in turn requires of the reader' (Nussbaum 1990, p.9). She suggests a dialectical approach to literature in which the literary texts are used to prompt discussions of philosophical and ethical questions and enable children to 'read for life'. In her opinion this does not mean a diminution of the novels, 'but rather an expression of the depth and breadth of the claims that those who love them make for them' (Nussbaum 1990, p.29). Nussbaum's dialectical approach also applies to the reading of children's books which describe how children constructed in literary texts struggle and cope with nerves, violence and step-parents in their families. The narratives offer a challenge to child readers to be constructive, reflect and engage in dialogues with the text and with peers and adults, and to 'negotiate this hybrid, or border country', for it is in the gap between imagination and reality, and the gap between being a child and being an adult, that the potential for negotiation lies (Rudd 1999, p.26, p.21). Children's books that thematise troubled families in modes which balance between seriousness and laughter or between seriousness and poetic imagery, have great potential for extending the boundaries of intellectual and emotional experience.

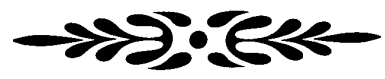




\section{REFERENCES}

Arvola, Ingeborg (2000) Blod, snørr og tårer (Blood, Snot and Tears). Oslo, Cappelen.

Bowlby, John (1979) The Making and Breaking of Affectional Bonds. London, BrunnerRoutledge.

Bowlby, John (1988) A Secure Base. London, Brunner-Routledge.

Dahle, Gro and Svein Nyhus (2003) Sinna mann (Angry Man). Oslo, Cappelen.

Eriksen, Endre Lund (2002) Pitbull-Terje går amok (Pitbull Terrier Runs Amok). Oslo, Aschehoug.

Hunt, Peter (2001) Children's Literature. Oxford, Blackwell Publishing.

Lothe, Jakob (2000) Narrative in Fiction and Film. An Introduction. Oxford, New York, Oxford University Press.

Nodelman, Perry (1999) 'Decoding the images: how picture books work' in Peter Hunt (ed.) Understanding Children's Literature. London and New York, Routledge, pp. 128-139.

Nussbaum, Martha C. (1990) Love's Knowledge. Essays on Philosophy and Literature. New York, Oxford, Oxford University Press,
Rudd, David (1999) 'Theorising and theories. How does children's literature exist?' in Peter Hunt (ed.) Understanding Children's Literature. London and New York, Routledge, pp.15-29.

Sandberg, Kristin A.(2004) Verdens ondeste stemor (The World's worst Stepmother). Oslo, Damm.

Sommer, Dion (2003) Barndomspsykologi. Udvikling i en forandret verden (Childhood Psychology: Development in a Changed World), Copenhagen, Reitzels Forlag.

Stephens, John (1999) 'Analysing texts: linguistics and stylistics' in Peter Hunt (ed.) Understanding Children's Literature. London and New York, Routledge, pp.73-85.

Watson, Victor (ed.) (2001) The Cambridge Guide to Children's Books in English. Cambridge, Cambridge University Press.

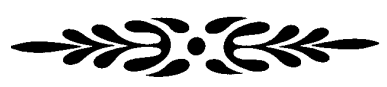

\section{BIOGRAPHICAL NOTE}

Anne-Kari Skardhamar is an associate professor at Oslo University College, Faculty of Education. She has published books on Faroese literature and on teaching literature, articles on children's literature and literary representations of childhood. 